towards the palm. Much pain was experienced, though to contact the finger was devoid of sensibility. Patient would insist on having the finger removed. I cut through the first phalanx a little above the metacarpal joint. There has been much less pain in the healing of this stump, owing, I imagine, to more diseased surface being removed. All the blood was collected and set aside, but in it no filaria was found. The tissues of the dissected finger gave also negative results, except the diseased scrapings of the joint. In these one filaria was found, which under the $\frac{1}{4}$-inch was seen to coil itself up repeatedly into a spiral of four close rings, after which it suddenly straightened itself. The presence of a worm which fills the field of the $\frac{1}{4}$-inch, and sets all the blond-cells into violent motion, when once seen, does not admit of doubt.

Case 11 of my first series in the Pathological Society's Transactions suffered in June from two abscesses of the arm. I obtained from each, in the matter discharged, a dead parent worm. I searched over much blood before $I$ found a single microscopic filaria. In winter it would seem that embryonic worms are not given off in great numbers.

Brisbane, July, 1879.

\section{A CASE OF FATAL PERITYPHLITIS FROM PERFORATION OF THE VERMIFORM APPENDIX BY AN ORANGE-PIP.}

\section{BY JOHN SERVICE, L.R.C.S. \& L.R.C.P. EDIN.,} SURGEON TO THE BOLDON COLLIERY, NEWCASTLE-ON-TYNE.

THE following case, which occurred in the practice of my friend Dr. Whamond, of Jarrow, whom I was assisting at the time, proves, I think conclusively, that foreign bodies do sometimes perforate the crecal appendix with fatal results.

Sarah Jane P-, of Monkton, in the parish of Jarrow, aged eleven, previously in good health, was suddenly seized on the night of Dec. lst, 1877, with a severe pain in the right iliac region. When seen shortly after, she was lying in bed with the right leg drawn up, an anxious expression on the face, and respiration performed with evident fear. Temperature slightly over normal. The chest sounds were natural ; there was no appearance of spinal disease, no deposit in the urine, and the bowels were unaffected; the tongue was moderately clean, nor did the girl complain of headache or thirst. An opiate was given and a blister applied to the part. Next day her condition was much the same, and the pain, though unaffected by large doses of opium, would yet, seemingly irrespective of any treatment, intermit for as long as three hours at a time. There was now slight fulness and slight percussion-dulness over the seat of pain, but both were very trifling and not constant. Her condition became gradually worse, rapid weak pulse, furred brown tongue, \&c., while the pain extended over the whole abdomen. Death occurred suddenly, with vomiting of black matter, at 9 A.M. on Dec. 14th, thirteen days from the beginning of the illness.

Necropsy, thirty hours after death.-The body was fairly nourished, and of the average size for the age. There were no external marks save that of the blister. The abdomen only was examined. An incision having been made through the linea alba, the peritoneum was found to be inflamed and adherent to the bowels. On section a large quantity of pus welled out from the right iliac fossa, and, together with what was now dipped and sponced ont, would amount to fully a quart. During the removal of the fluid a little greyish-white substance, of about the size and appearance of an orange-pip, was discovered and laid aside for subsequent examination. A large ashy-grey membrane, equal in size to a small saucer, was found attached to the cæcum, and a portion of the same material adherent to the tip of the vermiform appendix, which was perforated and had evidently communicated with the pyogenic membrane referred to. The kidneys and ureters were found to be healthy. We concluded that death had resulted from peritonitis, due to the bursting of a large abscess, which again had been caused by perforation of the crecal appendix by a foreign body impacted there, and a consequent extensive amount of perityphilitic inflammation.

On examining the foreign body found, it had the appearance already described, was soft, and cut readily with a knife. It was insoluble in water cold or lot, insoluble in nitric and in hydrochloric acids, but slightly soluble in nitro. hydrochloric with heat. The solution gave no precipitate with ammonic oxalate nor with hydro-disodic phosphate, proving it to be neither lime nor a phosphate; nor did it effervesce with an acid, showing the absence of a carbonate. On microscopic examination, a section of the substance shoved a distinct fibro-cellular structure mingled with a soft débris. Upon inquiry being made, it was found that the girl's father had brought home some oranges about a week previous to the beginning of her illness, and it was also ascertained that of these she ate one on the 25th of Novem. ber; that was six days before her illness began and nineteen days before death.

That from the presence of glandular elements within the appendix natural secretions may become the nuclei of small calculi, nobody, I think, can doubt; and even fæcal matter, as in the case reported by Dr. Maunsell Collins in TrE LANCER of December 13th, 1879, may occasionally lead to the same result; but, on the other hand, it seems to be equally certain that this trap in the alimentary canal may sometimes catch larger travelling substances, and has often done so, notwithstanding the high authorities quoted by Dr. Collins to the contrary. It would almost seem, indeed, as if popular belief pointed to some salutary lessons of the kind in the past. Who does not remember having been cautioned in childhood against the swallowing of fruitstones, "because they were poison" (as some of course are), or be. cause "a tree would grow up into the throat and produce suffocation"?

West Boldon.

\section{9 望tirtor}

\section{HOSPITAL PRACTICE, BRITISH AND FOREIGN.}

Nulla antem est alia pro certo noscendi via, nisi quamplurimas et morboram et dissectionum historias, tum aliorum, tum proprias collectas habere, et inter se comparare.-MorgagN I De Sed. et Caus. Morb., lib. iv. Procemium.

\section{GUY'S HOSPITAL.}

SURGICAL CASES ILLUSTRATING WOUND TREATMENT AND REPAIR.

(Under the care of Mr. BRYANT.)

THE following cases show that serious wounds may be made and repair take place under a plan of simple dressing, without the occurrence of any important rise of temperature or serious disturbance of the constitutional state.

Recurrent Sarcoma of Breast; Excision; Primary Union. (From notes taken by Mr. C. L. Jones.) - Matilda H-, fifty-one years old, was admitted into Lydia ward on April 30th, 1877. She had been in the hospital in October, 1874, and her right breast was then excised. The wound healed partly by primary intention and partly by granulations. About two years after that operation she noticed the tumour began to grow again at the lower part, and, latterly, had increased very rapidly. When admitted she appeared a fairly healthy-looking woman. There were enlarged veins over the remains of the right breast, and a large transverse scar entirely healed. There was a tumour rather larger than half an orange occupying the situation of the breast; it was irregularly circular in form ; the surface felt irregular, lobulated, not very hard, rather spongy, not adherent to skin or pectoral muscle, and there were no enlarged glands in the axilla.

On May 15th the patient was placed under the infuence of chloroform, and the growth was excised, the edoes of the wound being brought together with sutures. The growth appeared to be a typical sarcoma. There was some sickness after the chloroform, and she liad no sleep. Temperature $101 \cdot 3^{\circ}$; pulse 120 . On the 17 th she had quite recovered from the operation, and the wound seemed to have healed by first intention; temperature $100^{\circ}$, pulse 108 . On the 24 th the wound had liealed, and on the 25th she left the hospital. After the 17 th the temperature never exceeded normal. 